Article

\title{
Analysis of a Flash Flood in a Small Basin in Crete
}

\author{
Sofia Sarchani and Ioannis Tsanis * \\ School of Environmental Engineering, Technical University of Crete, 73100 Chania, Greece; \\ sofia.sarchani@hydromech.gr \\ * Correspondence: tsanis@hydromech.gr; Tel.: +30-28210-37799
}

Received: 8 September 2019; Accepted: 23 October 2019; Published: 28 October 2019

\begin{abstract}
Climate change will have a greater impact on the severity of flash floods, since precipitation intensity is expected to increase, even in areas where a reduction of precipitation is possible. This change in climate is expected to increase flood wave speed and its flood wave area extent. A case study of a small basin in the island of Crete was conducted to examine this effect, following the calibration and validation of the flow hydrograph of a flash flood event, in order to achieve model verification with the post-flood data. It was found that the most important parameters that affect the timing and magnitude of the peak discharge are the storage coefficient, the impervious rate and the curve number, as well as the time of concentration. Rainfall distribution was examined in different time intervals in order to study the effect of the intensity of precipitation on the peak hydrograph. From the precipitation records and according to the size of the watershed, the time step of the precipitation in the simulation model is recommended to be less than an hour. In other areas around the basin of interest, severe storms known as Medicanes that pass over Crete can produce higher precipitation in shorter time intervals. The impact of climate change scenarios results in an increase on the peak discharge by creating precipitation of higher intensity. Furthermore, the intensification of precipitation due to climate change results in higher flood depths and flooded area extent, as well as wave velocities.
\end{abstract}

Keywords: flash flood; calibration; validation; precipitation intensity; climate change; flood extent

\section{Introduction}

Flash floods are rapid and rushing floods in a stream or river that occur suddenly within a few minutes to six hours after a heavy rainfall [1-3]. These floods are mostly affected by rainfall characteristics (intensity, duration, quantity, space-time distribution), and the physical and hydrological characteristics of the basin, such as its extent, length, slopes, soil type, land uses, vegetation, previous conditions, etc. [4]. They usually occur over small river basins of a few tens and hundreds of $\mathrm{km}^{2}$. These floods are dangerous, as they can happen with little or no warning, limiting the forecasting time for an effective response regarding preparation and evacuation. They are frequently associated with a rapid increase in water levels, accompanied by high-speed moving waters, capable of dragging people and their cars out of their way [3]. Flash floods are also associated with short-lived, but high-intensity precipitation rates, mostly because of convective clouds, occurring locally. They occur especially in complex and intense terrain, where flow rate is promoted [5]. Additionally, these floods are regularly accompanied by landslides and mud flows. Small watersheds are rapidly flooded in an extreme precipitation event due to steep slopes and saturated soils. Urban areas are particularly vulnerable to flash floods, mostly because of existing large impermeable areas [1].

Plenty of studies have focused on hydro-meteorological characteristics of precipitation events [6-9], as well as on the analysis of flash floods' impacts [10,11], on the island of Crete. Climate change effect is expected to produce more intense and more frequent heavy precipitation events [12]. Many researchers 
have studied the hydrological impacts of climate change in several Mediterranean basins, based on different Representative Concentration Pathways [13,14], as well as bias-corrected and downscaled datasets from Global Climate Models and Regional Climate Models [15].

In this paper, the flash flood of 17 October 2006 in the Almyrida basin in Crete was simulated, using 15-min interval precipitation data, following the model calibration, sensitivity and order of magnitude analysis, as well as verification with post-flood field measurements that took into account uncertainties in the calculations of the basin's hydrogeological characteristics and parameters. The most important parameters affecting the produced hydrograph were the impervious rate, the curve number, the time of concentration and the storage coefficient. The one parameter at a time approach was followed, each one changing between its uncertainty limits. The produced hydrographs were validated through the post-flood measured high water mark level in the control cross section. The effect of rainfall's sampling time to the peak discharge was examined for different temporal distributions of precipitation data. Datasets of $5 \mathrm{~min}, 30 \mathrm{~min}, 1 \mathrm{~h}, 3 \mathrm{~h}, 6 \mathrm{~h}, 12 \mathrm{~h}$ and $24 \mathrm{~h}$ were used. Due to the fact that adjacent meteorological stations to the area of interest have already recorded more intense precipitation, climate change scenarios of decreasing peak precipitation by $34 \%$ and $57 \%$ for the event precipitation depth, and increases by a factor of 2.0 and 4.0 to the resulted average flow hydrograph were examined. The reason that we used reduced or intensified data of peak precipitation, similar to those of neighboring stations, in order to estimate the possible peak runoff of the hydrograph, is that we could not use the climate change EURO-CORDEX database due to the time-series being daily, and therefore, it was not suitable for use in small watersheds for modeling flash floods. In addition to significant changes in the peak outflow, the hydraulic analysis of the changing climate scenarios, with the use of topography extracted by a high resolution digital terrain model (DTM) $5 \mathrm{~m} \times 5 \mathrm{~m}$, displays remarkable differences in the water depths and the flooded area extent. For the examined climate change scenarios, there were changes in the velocities at the control cross section, changes in the average flood duration since the beginning of simulation and changes in the maximum flood wave arrival time at all flow areas.

\section{Materials and Methods}

\subsection{Study Area: Almyrida Hydrological Basin}

The hydrological basin of Almyrida (long $24^{\circ} 12^{\prime}$, lat $35^{\circ} 26^{\prime}$ ) is located in western Crete, and the northeast part of the Prefecture of Chania (Figure 1), about $20 \mathrm{~km}$ away from the city of Chania. The basin covers an area of $23.17 \mathrm{~km}^{2}$. The watershed has a moderate orography, with an average altitude of $197 \mathrm{~m}$, covering a range between 0 and $517 \mathrm{~m}$ above sea level. The area's topography varies, consisting of mild slopes to the largest extent, with the exception of a few areas having gradients of more than $10 \%$. Elevations are shown in Figure 1, as derived from the high resolution $5 \mathrm{~m} \times 5 \mathrm{~m}$ digital terrain model (DTM). Based on a 32-year observation period (1975-2007), the average annual rainfall in the basin was found to be $648.7 \mathrm{~mm}[11,16,17]$. The drainage of the basin is ephemeral, occurring only during rainfall [17].

Regarding the hydrogeology of the area, in the southern part of the basin, crystalline limestones are found, as well as marbles locally (29.4\%), and biogenic limestones, marls, clays and conglomerates $(40 \%)$ in addition. Karst cavities with clay deposits $(9.4 \%)$ are met to a lesser extent. In the northern part of the basin, marbles, phyllites, dolomites, quartzites and conglomerates in consecutive layers $(11.8 \%)$ are found, as well as alluvial deposits mainly along the streams' slopes $(4.4 \%)$. At the same time, carbonate layers of limestones and dolomites (5\%) are found across the basin. Karst limestones and dolomites, and marbles as well, which are mainly found in the basin, are granular or crystalline water-permeable formations, allowing infiltration and precipitated water transport through their grains. Quartzites, phyllites and conglomerates encountered are of low permeability. Clays and marls found in the basin are practically impermeable formations [18]. On the other hand, the small percentage of alluvial deposits found are transported materials over long distances through running water [19], and can be both gravel and sand [20], as well as clay, silt and organic mud [21]. Thus, classifying the 
rocks concerning their permeability, karst rocks of the study area mainly met in the higher altitudes were calculated to reach $64 \%$, whereas clays found in the plain were assumed to consist at $36 \%$.
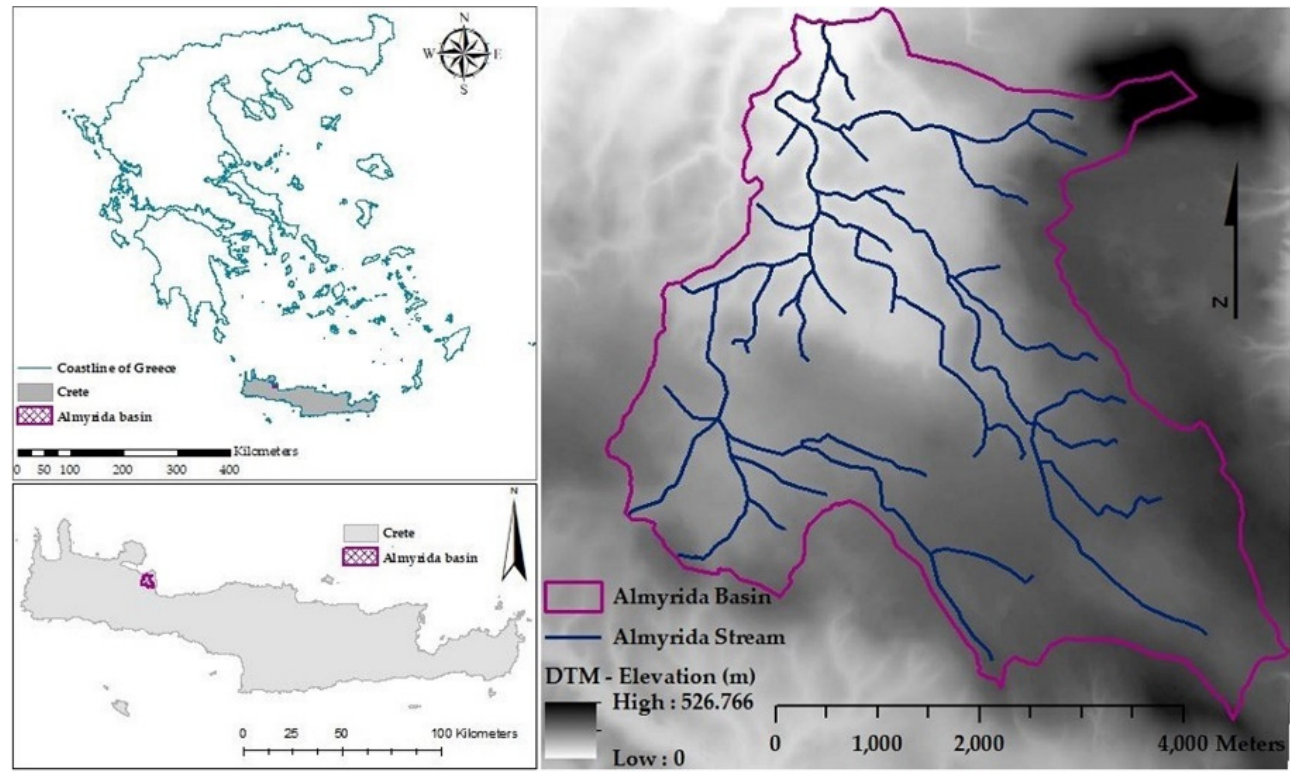

Figure 1. Almyrida basin in the island of Crete.

The climate of the wider region is characterized as Mediterranean, with warm dry summers and mild winters [17]. About $53 \%$ of annual rainfall occurs in winter, $23 \%$ throughout autumn and $20 \%$ throughout spring months, while there is negligible precipitation in the summer [11]. In Crete, average rainfall ranges from $440 \mathrm{~mm} /$ year in the east, to over $2000 \mathrm{~mm} /$ year in the western Crete, where the orographic effects tend to increase in frequency as well as the intensity of winter rainfall [6]. The above features, combined with rough terrain and small basins, make Crete susceptible to floods [11].

The study area is cultivated and mainly covered by olive groves. According to the European Union's CORINE 2000 Land Cover maps [22], the Almyrida basin is covered by olive trees $(40.56 \%)$, pastures $(4.52 \%)$, complex arable land areas $(10.94 \%)$, predominantly agricultural areas, with significant areas of natural vegetation $(16.34 \%)$, natural meadows $(1.57 \%)$ and sclerophyllous vegetation $(26.07 \%)$.

\subsection{Description of the Flash Flood Event of 17 October 2006 in Almyrida}

On 16 October 2006, a low pressure with center $1010 \mathrm{hPa}$, located in the central Mediterranean near Malta, moved eastwards, crossing over the island of Crete, with an estimated speed of about $65 \mathrm{~km} / \mathrm{h}$ being characterized as a Mediterranean tropical storm. On 17 October 2006 at 00:00 UTC, the frontal depression was centered west from Crete, where the cyclone deepened to even lower pressure levels than $1008 \mathrm{hPa}$ [11], causing a high-intensity but short-lived heavy precipitation event, resulting in a flash flood in the area of Almyrida. With the help of meteorological radar data, it became obvious that the system was a large cyclone, having a maximum diameter of approximately $200 \mathrm{~km}$. During the storm, there was movement of individual stormy cells inside the cyclone formation, with the center of the cyclone focusing on the northeast of the study area, which is a position of an orographic uplift from the mountain volumes in the south of the basin [23]. Due to the fact that the runoff of the watershed is ephemeral, there was no gauging equipment in the area [17]. The closest meteorological stations are the rain gauge at Souda bay, $16 \mathrm{~km}$ away from the area, which recorded a maximum hourly rainfall of $25.2 \mathrm{~mm}$, as well as the rain gauge in Kalyves, just $3 \mathrm{~km}$ away from the basin, which recorded daily precipitation of $220 \mathrm{~mm}$, far exceeding the 1\% of the Annual Exceedance Probability (AEP) of the particular station, assuming a 100-year return period [16]. The main water volume precipitated during $7 \mathrm{~h}$, from 07:00 to 14:00 local time [11]. Using terrestrial and radar data, the maximum precipitation 
intensity was estimated about $23 \mathrm{~mm} / \mathrm{h}$ [23], enhancing the surface flow and producing an estimated peak discharge of about $120 \mathrm{~m}^{3} / \mathrm{s}$. After topographic post-flood measurements by visible flood marks at a downstream control cross section located at the basin's outlet, as well as collected photos and permanent residents' reports [11], the runoff water depth was measured equal to $2 \mathrm{~m}$. An uncertainty in the measured water depth by $15 \%$ is assumed, because during post-field measurements mud, silt and gravels were deposited in the control cross-section during the precipitation event, resulting in an increase of the stream's datum by about $30 \mathrm{~cm}$. Soil moisture was very low before the extreme precipitation event, whereas it increased by almost 50\% after the flash flood [17]. Because of this extreme flood event, more than $€ 1$ million in damages was caused in the area of Almyrida, while the total amount of losses amounted to $€ 3$ million. Additionally, loss of a human life was recorded in the affected area [16].

\subsection{Climate Model Data}

The EURO-CORDEX database uses the representative concentration pathways (RCPs) defined by the 5th assessment report of the Intergovernmental Panel on Climate Change (IPCC) [12]. The RCPs included are the RCP2.6 strict mitigation scenario of greenhouse gas (GHG) emissions, the RCP4.5 intermediate scenario and the RCP8.5 scenario with very increased GHG emissions [24]. The Water Resources Department of the Decentralized Administration of Crete provided the precipitation data which were monitored by 21 hydro-meteorological stations for the historical period of 1981-2010. Those historical precipitation data were statistically bias-corrected with the Multi-segment Statistical Bias Correction method [25], in which quantiles are matched. The bias-corrected data are projected to 2100 and follow the procedure of the climatic data produced from the Climate Service Center REMO (CSC-REMO) regional climate model (RCM) simulations, being influenced by the Max Planck Institute Earth System Model, low resolution, reanalysis 1 (MPI-ESM-LR-r1) driving global climate model (GCM). Full climate change impact analysis was performed in the island of Crete by Nerantzaki et al. [26] and Tapoglou et al. [27] for the 1981-2100 period. Climate change impact on precipitation was limited to daily data, with the maximum daily precipitation derived by the GCM-RCM for the RCP4.5 emissions' scenario being equal to $340 \mathrm{~mm}$, which is not appropriate to be used in flash floods in a small basin. Figure 2 represents the climate change CORDEX grid of $12.5 \times 12.5$ spatial resolution $\left(0.11^{\circ}\right.$ resolution $)$ of the Island of Crete and the location of the Almyrida watershed.

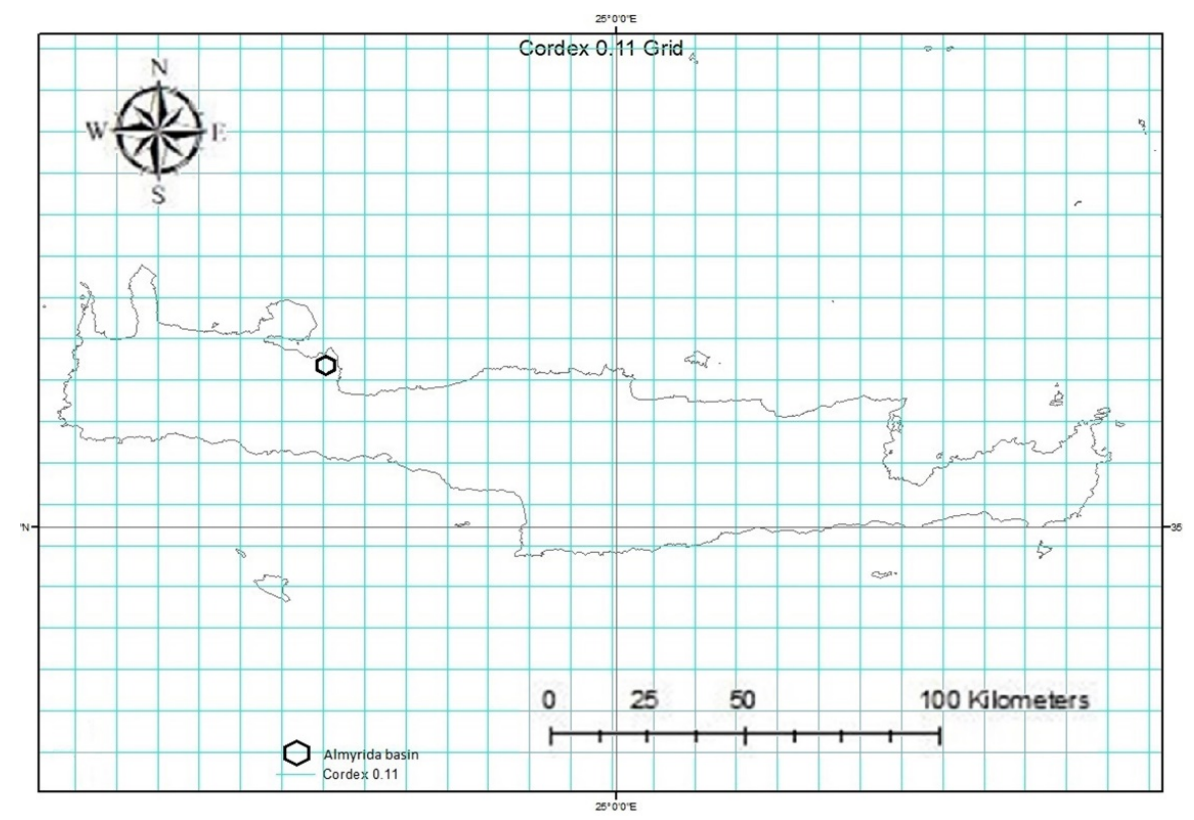

Figure 2. CORDEX grid of $12.5 \times 12.5$ spatial resolution of Crete and location of Almyrida basin. 


\subsection{Hydrological Modeling}

The U.S. Army Corps of Engineers' Hydrologic Engineering Center developed the Hydrologic Modeling System (HEC-HMS) 4.2.1 model, which is designed to simulate rainfall-runoff processes in dendritic hydrological basins. It can be applied in a broad range of geographical territories to solve a large series of problems, such as wide river basin drainage and the possible hydrological flooding, as well as the discharge of small urban or natural basins. In the studied watershed, outflow is calculated from meteorological data by removing losses, transforming the excess precipitation, and adding the baseflow [28]. Most of the models included in the HEC-HMS hydrological software are event models that simulate a single storm. At the same time, the main models included are lumped, with a few exceptions of distributed models. Both measured-parameter models and fitted-parameter models are included. Some models are empirical, and therefore, their parameters cannot be measured, while on the contrary, for the selected basin, the parameters' values resulted from calibration. However, in other models, there are parameters that can be determined by soil characteristics [29].

A lot of alternative models are included in HEC-HMS for counting the cumulative losses in order to estimate the runoff volume. The most appropriate implementation method to use in this study is the SCS Curve Number loss model, as it is a simple, predictable, stable and well-established method, widely accepted for use [30]. The particular loss model estimates the cumulative excess precipitation $P_{e}$ $(\mathrm{mm})$ at time $t$ as a function of cumulative precipitation, soil cover, land uses and antecedent moisture conditions [31], using the following equation:

$$
P_{e}=\frac{(P-0.2 S)^{2}}{P+0.8 S}
$$

where $P(\mathrm{~mm})$ is the accumulated rainfall depth at time $t$ and $S(\mathrm{~mm})$ is the potential maximum retention. The difference between the accumulated excess rainfall at the end and beginning of a period estimates the incremental excess for a time interval.

The initial abstraction (initial loss) is given by the empirical relationship:

$$
I_{a}=0.2 S
$$

The potential maximum retention $S(\mathrm{~mm})$ and the basin's characteristics are related through the curve number $\mathrm{CN}$ [31] with the equation:

$$
S=25.4 \times\left(\frac{1000}{C N}-10\right)
$$

where the $C N$ (dimensionless) of a basin is estimated as a function of land uses, soil type and antecedent moisture conditions, using tables published by the Soil Conservation Service, ranging from approximately 30 for permeable soil with high infiltration rates to 100 for water bodies [30].

HEC-HMS includes many alternative models for representing basin's direct runoff. The Clark UH model, which is the one used in this paper, is a lumped parameter model appropriate for the studied event, based on a quasi-conceptual calculation of basin's storage [30]. In the Clark UH model, runoff computations estimate two critical processes in transforming the excess precipitated water to discharge: translation, which is the movement of the excess rainfall, and storage. Translation is connected with time of concentration $T_{c}$. Storage is estimated with the linear reservoir model. At time $t$, storage $S_{t}$ is related to outflow as:

$$
S_{t}=R O_{t}
$$

where $R$ is the storage coefficient for linear reservoir and $O_{t}$ is the outflow from storage at time $t$, given as:

$$
O_{t}=\frac{\Delta t}{R+0.5 \Delta t} I_{t}+\left(1-\frac{\Delta t}{R+0.5 \Delta t}\right) O_{t-1}
$$


where $\Delta t$ is the time interval, the average inflow to storage at time $t_{;}$, and $O_{t-1}$ is the outflow from storage at former time $t-1$ [30].

Regarding the representation of basin's baseflow, HEC-HMS includes a few alternative models. The exponential recession model is the one used in this study [32], explaining the drainage from natural storage in the studied basin. This model determines the following equation of calculating the baseflow $Q_{t}$ at any time $t$ :

$$
Q_{t}=Q_{0} k^{t}
$$

where $Q_{0}$ is the initial baseflow at time $t$ equal to zero, which may be specified either as a flow rate $\left(\mathrm{m}^{3} / \mathrm{s}\right)$, or as a flow per area $\left(\mathrm{m}^{3} / \mathrm{s} / \mathrm{km}^{2}\right)$, and $k$ is an exponential decay constant, defined as the ratio of the baseflow at time $t$ to the baseflow one day earlier.

The recession model is applied not only at the beginning of simulating a precipitation event but also later, as the delayed subsurface discharge reaches the basin's channels. Because total flow is calculated as the sum of baseflow and direct surface runoff, after the peak of direct runoff, a threshold flow determines the time at which the recession model defines the total flow. The threshold may be determined either as a flow rate, or as a ratio to the computed peak flow (ratio-to-peak). The later total discharges are estimated with $Q_{0}$ being equal to the specified threshold [32].

\subsection{Hydraulic Modeling}

The U.S Army Corps of Engineers' River Analysis System (HEC-RAS) 5.0.3 one-dimensional (1D) model, developed by the Hydrologic Engineering Center, was used for the analysis of the studied extreme event, causing Almyrida stream's and the relevant floodplain areas' flooding. The unsteady flow simulation component of the HEC-RAS 5.0.3 model is able to simulate 1D unsteady flow through a full open channel network, performing subcritical, supercritical and mixed flow calculations [33]. The principles governing the water flow in a stream are the conservation of mass (continuity) and the conservation of momentum, which are mathematically expressed with the partial differential equations of continuity and momentum, respectively. Conservation of mass for a control volume indicates that the net flow rate into the volume is equal to the rate of change of storage within the volume [34]. The final form of the continuity equation is given as:

$$
\frac{\partial A_{T}}{\partial t}+\frac{\partial Q}{\partial x}-q_{L}=0
$$

where $A_{T}\left(\mathrm{~m}^{2}\right)$ is the total flood area, $Q\left(\mathrm{~m}^{3} / \mathrm{s}\right)$ is the total flow as a function of distance $x$ and time $t$ and $q_{L}\left(\mathrm{~m}^{2} / \mathrm{s}\right)$ is the lateral inflow per unit length [34].

Conservation of momentum for a control volume is expressed by Newton's 2nd law, stating that the net rate of momentum entering the volume plus the sum of all the external forces acting on the volume is equal to the rate of accumulation of momentum [34]. The final form of the momentum equation is given as:

$$
\frac{\partial Q}{\partial t}+\frac{\partial Q V}{\partial x}+g A\left(\frac{\partial z}{\partial x}+S_{f}\right)=0
$$

where $Q\left(\mathrm{~m}^{3} / \mathrm{s}\right)$ is the total flow as a function of distance $x$ and time $t, V\left(\mathrm{~m}^{3}\right)$ is the control volume, $g\left(\mathrm{~m} / \mathrm{s}^{2}\right)$ is the acceleration of gravity, $A\left(\mathrm{~m}^{2}\right)$ is the total flood area, $\partial z / \partial x$ (dimensionless) is the water surface slope and $S_{f}$ (dimensionless) is the friction slope [34].

\subsection{Simulation of the Precipitation Event of 17 October 2006 Using the Hydrological HEC-HMS Model}

Geographic information systems (GIS) have been used for the last 20 years, closely-coupled with models that simulate many environmental/water resources applications in integrated modules $[35,36]$. An integrated hydrological/hydraulic system is the HEC-HMS and HEC-RAS, which provide model functionality. The modeling of the studied precipitation event was performed via the hydrological HEC-HMS 4.2.1 model. The shapefiles of the hydrological basin and the Almyrida stream, created in 
ArcGIS 10.1, were initially imported, and then, two hydrological elements were placed, a sub-basin and an outlet of the system, composing the examined hydrological system. A new time-series was created, including the gage weights precipitation data, according to the records of Souda bay's rain gauge, reduced per $15 \mathrm{~min}$, for two days, from 16 October 2006 at night to 18 October in the evening. The cumulative precipitation was $196.2 \mathrm{~mm}$, until 18 October at 22:00 in the evening. The meteorological model was created, and Gage Weights Precipitation was chosen as the precipitation method. Hydrological simulation calculations were performed from 16 October 2006 at 23:30 to 18 October 2006 at 22:00, with a 15-min time step.

Hydrological Modeling Methods

SCS Curve Number was the selected loss method, which calculates the excess rainfall directly on the surface. Initial abstraction $\left(I_{a}\right)$, Curve Number $(C N)$ and Impervious $(\%)$ are the three parameters that concern the method. For different soil types and different land uses $(L U)$, the $C N$ of a basin is calculated as the individual sums of $\% L U$ on the corresponding curve number, given as:

$$
C N=\sum_{i=1}^{N}\left(\% L U_{i} \times C N_{i}\right)
$$

The $C N$ of the basin depends on land uses, soil type and antecedent soil moisture conditions. Due to the fact that both the southern and northern part of the basin consist of karstic rocks with clay deposits either of loamy rocks with sand, and not by clays or clayey muds, the soil type was not evaluated to be spatially varying. Thus, the soil group type A was used, consisting of sand, loamy sand or sandy loam. Group A soils have low runoff potential and high infiltration rates even when thoroughly wetted, consisting chiefly of deep, well to excessively drained sands or gravels, which at the same time are characterized by a small amount of clay, while having a high rate of water transmission $[37,38]$. The hydrological conditions display the effects of cover type, infiltration and runoff and are generally estimated from plants' density and residue cover on sample areas. Poor hydrological conditions point out reduced infiltration and tendency of increased discharge, while good hydrological conditions suggest increased infiltration, tending to decrease runoff. The hydrological conditions of the area are considered as fair [30,37]. In the Almyrida area, prior to the flash flood event of 17 October 2006, there had been no rainfall for a period of 5 months, except for 11 and 12 October where there was a recorded rainfall depth of $21 \mathrm{~mm}$ [17]. The resulting soil moisture conditions are characterized as Type II (average) moisture conditions, as they are classified within the range of $13 \mathrm{~mm}$ to $28 \mathrm{~mm}$ of the previous 5 days' rainfall during the October's dormant season [39].

Curve numbers per $L U$, for cultivated and other agricultural lands in the Almyrida basin, are given for soil group A, fair hydrological conditions and average moisture conditions in [37]. Because of the use of Land Cover maps of 2000 [22], there might be changes in current existing land uses. The values of the curve number for the land use categories are: olive trees (64), pastures (49), complex cultivated land areas (69.5), predominantly agricultural areas, with significant areas of natural vegetation (69.5), natural meadows (30) and scleroplyllous vegetation (35).

Therefore, the $C N$ of the basin is equal to 56.73. $I_{a}$, which expresses the amount of rainfall in the soil before the surface runoff, and can be set to $20 \%$ of the potential maximum retention $(S)$ [28,30], where $S$ is calculated in $\mathrm{mm}$ from the relationship (3) given above.

Hence, $I_{a}$ is equal to $38.75 \mathrm{~mm}$. We considered $\pm 15 \%$ uncertainty in the $C N$ calculation, because the Land Cover maps used were produced in 2000, and there might be slight differences in the current values of land uses. A one parameter at a time approach was considered for calibrating the hydrological model. Since we do not know the current land cover, the uncertainty of $\pm 5 \%$ to $\pm 15 \%$ in $C N$ results in a $C N$ range from 53.89 to 59.57 and from 48.22 to 65.24 , respectively. Monte Carlo sampling for examining the $C N$ uncertainty would be appropriate if we had adequate field data, although it would not improve the predictions. \% Impervious was calibrated for a range of $(16.08-29.04 \%)$, based on 
the geological composition of the watershed, as calculated in Table 1. As already mentioned, karst rocks, mainly found in the higher altitudes of the study area, consisting of crystalline limestones, marbles, biogenic limestones, karst cavities and dolomites, as well as carbonate layers of limestones and dolomites, reach $64 \%$; clay formations found in the plain, consisting of marls, clays, conglomerates, phyllites, quartzites and alluvial deposits, reach $36 \%$. At the highest altitudes, it was assumed that $60 \%$ of the rain falls, while at the lower altitudes, $40 \%$ of the rain falls. For the study area, karst rocks at higher altitudes may have an impervious rate of $10 \%$ to $40 \%$. The clay imperviousness of the plain can range from $85 \%$ to $95 \%$.

Table 1. Calculation of \% range of total basin's imperviousness.

\begin{tabular}{|c|c|c|c|c|c|c|}
\hline $\begin{array}{l}\text { \% Karst Mainly at } \\
\text { High Altitudes }\end{array}$ & $\begin{array}{c}\% \text { Clays Mainly } \\
\text { at Plain }\end{array}$ & $\begin{array}{c}\% \text { Rainfall at High } \\
\text { Altitudes }\end{array}$ & $\begin{array}{l}\% \text { Rainfall } \\
\text { at Plain }\end{array}$ & $\begin{array}{c}\text { \% Impervious at } \\
\text { High Altitudes }\end{array}$ & $\begin{array}{c}\text { \% Impervious } \\
\text { at Plain }\end{array}$ & $\begin{array}{c}\% \text { Range of Total } \\
\text { Basin's Impervious }\end{array}$ \\
\hline 64 & 36 & 60 & 40 & 10 & 85 & 16.08 \\
\hline 64 & 36 & 60 & 40 & 10 & 90 & 16.8 \\
\hline 64 & 36 & 60 & 40 & 15 & 85 & 18 \\
\hline 64 & 36 & 60 & 40 & 15 & 90 & 18.72 \\
\hline 64 & 36 & 60 & 40 & 15 & 95 & 19.44 \\
\hline 64 & 36 & 60 & 40 & 20 & 95 & 21.36 \\
\hline 64 & 36 & 60 & 40 & 25 & 85 & 21.84 \\
\hline 64 & 36 & 60 & 40 & 25 & 90 & 22.56 \\
\hline 64 & 36 & 60 & 40 & 25 & 95 & 23.28 \\
\hline 64 & 36 & 60 & 40 & 30 & 85 & 23.76 \\
\hline 64 & 36 & 60 & 40 & 30 & 90 & 24.48 \\
\hline 64 & 36 & 60 & 40 & 40 & 85 & 27.6 \\
\hline 64 & 36 & 60 & 40 & 40 & 90 & 28.32 \\
\hline 64 & 36 & 60 & 40 & 40 & 95 & 29.04 \\
\hline
\end{tabular}

Clark Unit Hydrograph was the chosen surface transform method, which is a lumped method. The two parameters that concern it are: the time of concentration $T_{\mathcal{c}}$, that is, the time required in order that the rainwater in the most distant point reaches the watershed's outlet, and the storage coefficient $R$ [28], expressing the temporary storage of excess precipitation in the basin as it drains. There are many empirical equations in order to calculate $T_{\mathcal{c}}$, depending on several geomorphological parameters. Thus, the empirical formula of Giandotti, which was developed for watersheds in Italy ranging from $170 \mathrm{~km}^{2}$ to $70,000 \mathrm{~km}^{2}$, being widely used in Mediterranean catchments for calculating $T_{\mathcal{C}}(\mathrm{h})$ [40] is:

$$
T_{c}=\frac{4 \sqrt{A}+1.5 L}{0.8 \sqrt{\Delta H}}
$$

where $A$ is the area of the basin equal to $23.17 \mathrm{~km}^{2}, L$ is the length of the main thalweg equal to $11.705 \mathrm{~km}$ and $\Delta H$ is the difference in mean elevation from outlet's elevation equal to $197.17 \mathrm{~m}$, as derived from the ArcGIS design.

Another empirical formula widely used for calculating $T_{\mathcal{c}}(\mathrm{h})$ is the one of Kirpich, which was developed for rural watersheds in Tennessee ranging from $0.004 \mathrm{~km}^{2}$ to $0.453 \mathrm{~km}^{2}$ and having slopes from $3 \%$ to $10 \%$ [41], as follows:

$$
T_{c}=0.0663 \frac{L^{0.77}}{S^{0.385}}
$$

where $S$ is the slope of the main thalweg equal to $0.026159 \mathrm{~m} / \mathrm{m}$, as measured in ArcGIS. Therefore, $T_{\mathcal{c}}$ was equal to $3.28 \mathrm{~h}$ regarding the Giandotti's formula, whereas it was equal to $1.79 \mathrm{~h}$ with respect to the Kirpich's equation. Adjustment factors are superposed by many scientists thus far, in order to bias correct the estimations of $T_{c}$, due to application of the aforementioned empirical formulas to catchments of different location and geomorphology of the ones originally fitted [42-44]. A correction 
factor of 2.0 may be applied to general overland flow and natural grass channels, whereas a correction factor of 1.0 can be adjusted to overland flow on bare soil or roadside ditches [32]. The examined area was considered to be covered by natural grass or being bare soil. Therefore, and at the same time because of the difference in calculated values of $T_{\mathcal{c}}$ through Kirpich's and Giandotti's formulas, uncertainty was examined via the adjustment factors of the Kirpich's equation of 1.15, 1.3 and 1.416, which yielded to $T_{c}$ values equal to $2.06 \mathrm{~h}, 2.33 \mathrm{~h}$ and $2.535 \mathrm{~h}$ respectively.

Many studies have verified that $R /\left(T_{c}+R\right)$ remains constant in an area, with values ranging from 0.1 , representative of runoff in an urban basin, to 0.7, representing a flat and marshy watershed [45]. The Almyrida basin is not an urban area, except from a very small percentage at its outlet, and at the same time, it is not a flat and swampy area, as besides natural meadows and agricultural lands, it comprises $\sim 67 \%$ of olive trees and sclerophyllous vegetation. Therefore, the approximation of the ratio $R /\left(T_{c}+R\right)=0.2-0.35$ is considered to be closer to reality.

Finally, Recession was the selected baseflow method, by which the baseflow's recession after a precipitation event in a basin, exponentially decaying, was modeled. A prerequisite for the method is to determine the initial baseflow, which is defined as the water volume per area and per time. For the studied hydrological basin, the initial discharge per area was assumed to be low enough and equal to $0.025 \mathrm{~m}^{3} / \mathrm{s} / \mathrm{km}^{2}$, due to the fact that soil moisture was quite low before the extreme precipitation event [17], leading to an initial baseflow equal to $0.6 \mathrm{~m}^{3} / \mathrm{s}$. The recession constant describes the baseline drainage rate between two storm events, and is defined as the ratio of the baseline amount measured at a given point in time to the corresponding baseline amount measured one day earlier [28]. Recession constant $k$ can range between 0.3 , being representative of small catchments, and 0.8 , regarding large catchments [46]. Thus, the exponential decay constant was chosen equal to 0.3 . The selected return method of the baseflow to its original level, after the end of a precipitation event, was the ratio to peak. The baseflow will be reset to its original level when the current flow divided by the maximum flow of the precipitation event drops to the specified value [28]. Tests regarding the ratio to peak among values of 0.05 and 0.2 did not produce changes at all in peak discharge; thus, it was assumed that the ratio to peak was equal to 0.05 .

\subsection{Geometry Data in ArcGIS—Connection to 1D HEC-RAS}

Using ArcGIS 10.1 software, a high-resolution $5 \mathrm{~m} \times 5 \mathrm{~m}$ digital terrain model (DTM) was entered in the spatial reference projection WGS 1984 UTM Zone 35N, which was converted to a TIN model. HEC-GeoRAS 10.1, an extension of HEC-RAS to ArcGIS 10.1, was used for the digitization of the downstream segment of Almyrida stream's centerline, having a length of $784 \mathrm{~m}$ : the bank lines of the stream, the flow path lines above the banks and along the main channel and 33 cross section cut lines, mostly perpendicular to the centerline of the stream, as shown in Figure 3. Each cross section covers the whole area of the floodplain. Thus, the cross sections' width ranges from 178 to $612 \mathrm{~m}$. After attributing features to Almyrida stream's centerline and to cross section cut lines, the geometry data were exported in HEC-RAS 5.0.3 [47].

\subsection{Analysis of the Downstream Segment of Almyrida Stream Using the Hydraulic 1D HEC-RAS Model}

The hydraulic simulation of the downstream segment of Almyrida stream due to the flash flood event of 17 October 2006 was carried out through the 1D HEC-RAS 5.0.3 model. The geometry created via HEC-GeoRAS was introduced to HEC-RAS in S.I. For unsteady flow, as the studied one is characterized, empirical coefficients of contraction and expansion equal to 0.1 and 0.3 , respectively, were set for the 33 cross sections [33]. The Manning friction coefficient $n$ for channels vary according to the type of channel and the detailed description. For the main channel which is clean, straight, full stage, with no rifts or deep pools, with more stones and weeds, the maximum value of the Manning roughness coefficient is equal to 0.04 , while for floodplains that are described as cleared land with tree stumps with heavy growth of sprouts is equal to 0.08 [48]. An existing bridge cross section was also created at $113.161 \mathrm{~m}$ before the stream's discharge. The upstream distance of the bridge from the 
previous cross section is $4 \mathrm{~m}$. The superstructure takes place at an elevation of $4.74 \mathrm{~m}$, has $9.50 \mathrm{~m}$ width and $1.40 \mathrm{~m}$ thickness. The weir coefficient for flow higher than the superstructure was set equal to 1.4. A maximum allowable submergence ratio during weir flow calculations above the bridge deck was also set equal to 0.98 . The head water maximum elevation above the bridge was defined at $6 \mathrm{~m}$ [33].

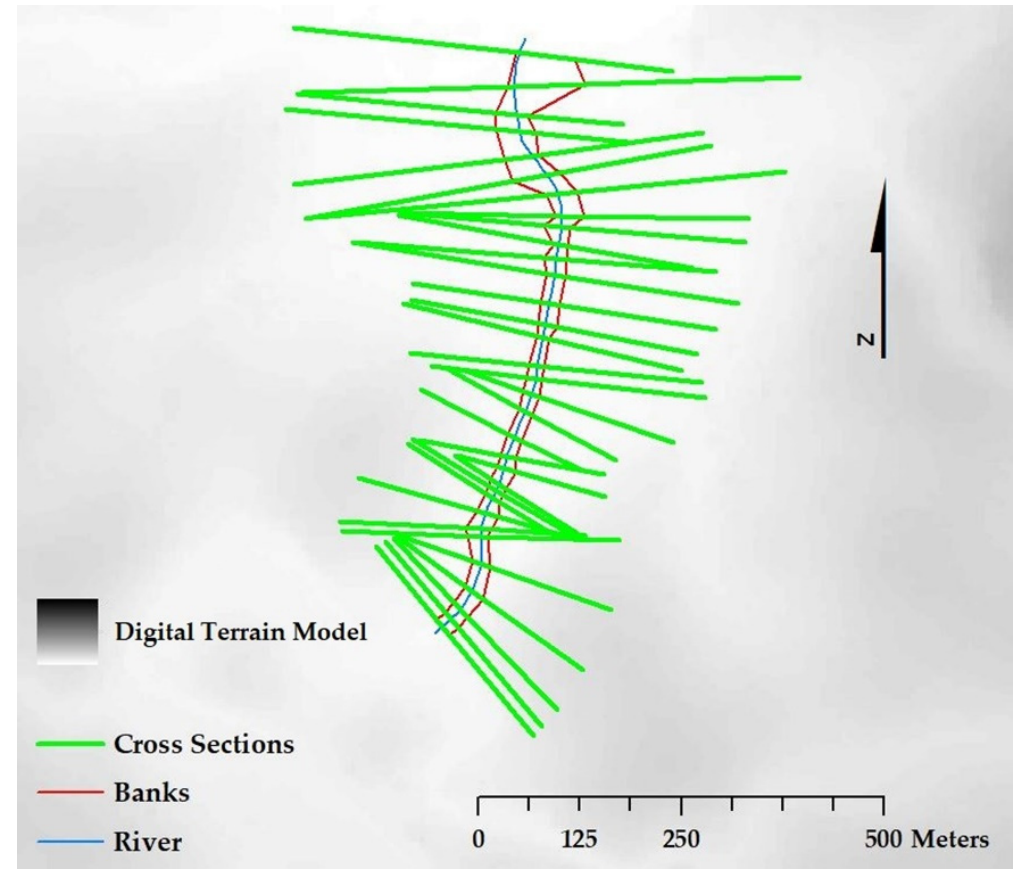

Figure 3. Almyrida stream's centerline, left-right banks and cross-sections, on a high resolution $5 \mathrm{~m} \times$ $5 \mathrm{~m}$ DTM.

The terrain model was created in RAS Mapper for DTM $5 \mathrm{~m} \times 5 \mathrm{~m}$, spatially referenced in WGS 1984 UTM Zone 35N projection. Figure 4 shows the final representation of the DTM and the georeferenced stream's geometry as well. Besides the chromatic representation of terrain elevations, the contours are also shown every $5 \mathrm{~m}$. There is also a hill shade, with areas having higher altitudes being brighter, while the lower altitude surfaces are darker, creating a sense of faux three-dimensional (3D) representation of the terrain. A Google hybrid map was added as a background map to the RAS Mapper to better visualize the studied stream's segment [33].

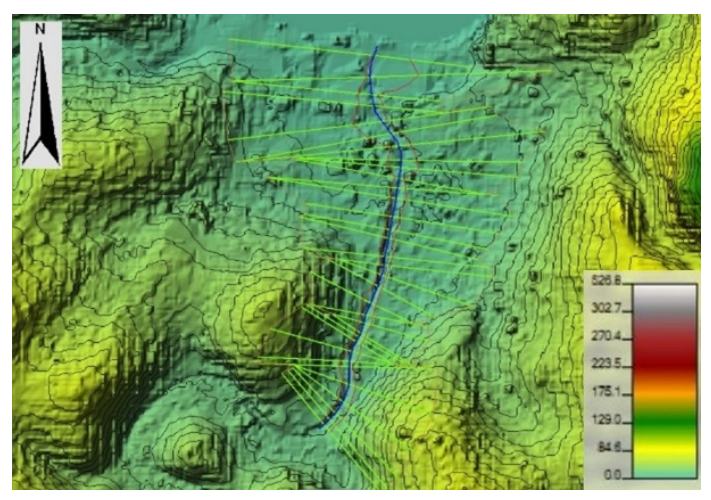

(a)

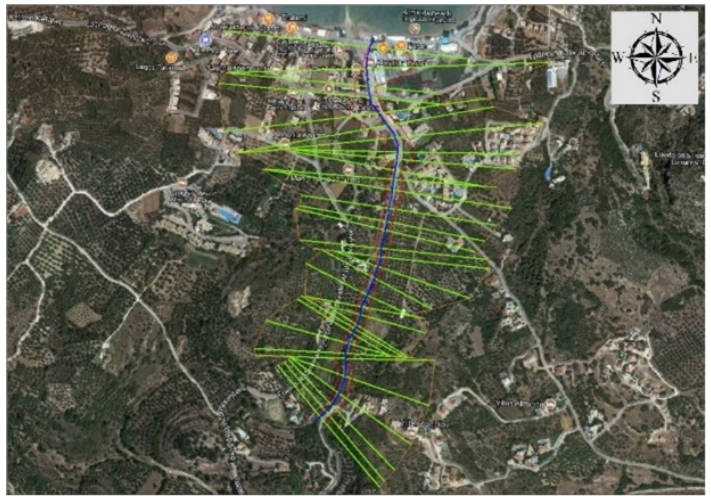

(b)

Figure 4. (a) Terrain model (resolution $5 \mathrm{~m}$ ) and geometry of downstream reach of the Almyrida stream georeferenced to WGS 1984 UTM Zone 35N on the RAS Mapper; (b) studied geometry on Google hybrid. 
Boundary conditions of unsteady flow were introduced; at the upstream end of the studied reach, the flow hydrograph boundary condition, as derived by HEC-HMS, was introduced from 17 October 2006 at 08:00 until 18:00, with a 15-min time step. The maximum flow change, without changing the time step, was set equal to $0.1 \mathrm{~m}^{3} / \mathrm{s}$. If this value was exceeded, half time step reduction took place until the change in flow rate did not exceed the maximum set. A minimum flow to be used in the hydrograph was also defined at $1 \mathrm{~m}^{3} / \mathrm{s}$. At the downstream end, the normal depth boundary condition of unsteady flow, which uses the Manning equation to estimate the water depth in each cross section, was introduced. The value for the friction slope was 0.03 . At the beginning of the unsteady flow simulation, at the upstream end, the initial flow condition was set to equal $1 \mathrm{~m}^{3} / \mathrm{s}$ [33].

Regarding the unsteady flow analysis, hydraulic calculations were performed from 17 October 2006 at 08:00 until 18:00, with a computation interval of $10 \mathrm{sec}$. The geometric data pre-processor, the unsteady flow simulator and the output post-processor were chosen to be performed. The hydrograph output interval and the detailed output interval were set equal to $10 \mathrm{~min}$. A mixed flow regime was also selected. Froude's number threshold value for eliminating acceleration terms was set equal to 0, while the exponent for Froude's number reduction factor was set equal to 10. By reducing these values, the stability of the system increases, but the accuracy of results decreases. Conversely, with the increase of those values, system stability decreases, but the accuracy of results increases. Time slicing was set to start after the fifth iteration, with a minimum iteration time step every $0.01 \mathrm{~h}$. The calculation options and tolerances for 1D unsteady flow simulation were also set. The theta implicit weighting factor was defined equal to 1, yielding greater stability in the solution, which may not be so accurate. The water surface calculation tolerance for each cross section was set equal to 0.006 $\mathrm{m}$. The maximum number of iterations, which was set to solve the unsteady flow equations, was equal to the upper allowable limit, which is 40 . During the "warm-up" period, the number of time steps was set equal to 200. The average friction slope was additionally chosen for the existing bridge [33].

\section{Results}

\subsection{Calibration of the Hydrological Modeling and Parameter Sensitivity Analysis}

For the studied basin, using the assumed values of initial discharge per area $\left(\mathrm{m}^{3} / \mathrm{s} / \mathrm{km}^{2}\right)$, recession constant and ratio to peak, the remaining parameters regarding imperviousness (\%), $C N, T_{c}$ and storage coefficient $R$, are calibrated. Sensitivity analysis of the model is performed to determine which of the calibrated parameters change the time of appearance of peak discharge, while checking which parameters affect the magnitude of peak discharge. The approach of one parameter change at a time is followed, each one for the aforementioned ranges of the hydrological modeling methods' section. The impervious rate is examined first, followed by the storage coefficient, the $C N$ and the time of concentration, respectively. It was found that an increase in the impervious rate results in an increase of the magnitude of peak discharge without changing the timing of peak. On the other hand, an increase of the storage coefficient causes a decrease in peak discharge, followed by a forward time shift of the peak. The increase of the $C N$ also increases the magnitude of the peak runoff with no change to the simulated time of appearance of the peak discharge. Finally, the time of concentration seems to appear as the most sensitive parameter, with the largest time shifts of peak discharge and variations of peak runoff. The lower time of concentration results in higher maximum discharge. Calibration of the aforementioned parameters is achieved by 42 runs that result in various depths of the downstream control cross section. Due to the fact that the study basin is ungauged, and therefore, no runoff data exist at the outlet (during heavy storm events, even the gauged basins do not provide runoff data during the flood due to the destruction of the flow measuring equipment), post-flood calibration of the hydrological model was applied. This was achieved through discussion with the locals about timing of the flood wave, which was reported to have occurred at noon. The simulated hydrographs were used as an input to the hydraulic model and the resulting flood waves were validated through the measured flood mark of the maximum water depth in the post-flood control cross section of $2 \mathrm{~m}$ [11], having a 
measurement uncertainty of $15 \%$. The flow hydrograph that verifies the time of peak as well as the maximum flood depth in the control cross section is correct. The detailed results of the performed tests are shown in Table 2.

Table 2. Parameter calibration by conducting sensitivity analysis, magnitude peak discharge analysis and model verification.

\begin{tabular}{|c|c|c|c|c|c|c|c|c|}
\hline $\mathbf{A} / \mathbf{A}$ & $\begin{array}{l}\text { Impervious } \\
(\%)\end{array}$ & $C N$ & $\begin{array}{c}\text { Time of } \\
\text { Concentration } T_{c}(\mathrm{~h})\end{array}$ & $\frac{R}{T_{c}+R}$ & $\begin{array}{c}\text { Storage } \\
\text { Coefficient } R(\mathrm{~h})\end{array}$ & $\begin{array}{l}\text { Peak Discharge } \\
\left(\mathrm{m}^{3} / \mathrm{s}\right)\end{array}$ & $\begin{array}{l}\text { Time of } \\
\text { Peak }\end{array}$ & $\begin{array}{l}\text { Depth in Downstream } \\
\text { Cross Section (m) }\end{array}$ \\
\hline 1 & 16.08 & 56.73 & 2.535 & 0.3 & 1.09 & 101.4 & $12: 00$ & 2.21 \\
\hline 2 & 16.8 & 56.73 & 2.535 & 0.3 & 1.09 & 102.2 & $12: 00$ & 2.22 \\
\hline 4 & 18 & 56.73 & 2.535 & 0.3 & 1.09 & 103.6 & $12: 00$ & 2.22 \\
\hline 5 & 18.72 & 56.73 & 2.535 & 0.3 & 1.09 & 104.5 & $12: 00$ & 2.22 \\
\hline 6 & 19.44 & 56.73 & 2.535 & 0.3 & 1.09 & 105.3 & 12:00 & 2.23 \\
\hline 7 & 19.92 & 56.73 & 2.535 & 0.3 & 1.09 & 105.9 & $12: 00$ & 2.23 \\
\hline 10 & 21.84 & 56.73 & 2.535 & 0.3 & 1.09 & 108.1 & 12:00 & 2.23 \\
\hline 11 & 22.56 & 56.73 & 2.535 & 0.3 & 1.09 & 109 & $12: 00$ & 2.24 \\
\hline 12 & 23.28 & 56.73 & 2.535 & 0.3 & 1.09 & 109.8 & $12: 00$ & 2.24 \\
\hline 13 & 23.76 & 56.73 & 2.535 & 0.3 & 1.09 & 110.4 & 12:00 & 2.24 \\
\hline 14 & 24.48 & 56.73 & 2.535 & 0.3 & 1.09 & 111.2 & 12:00 & 2.24 \\
\hline 15 & 25.2 & 56.73 & 2.535 & 0.3 & 1.09 & 112 & $12: 00$ & 2.25 \\
\hline 21 & 29.04 & 56.73 & 2.535 & 0.3 & 1.09 & 116.5 & 12:00 & 2.26 \\
\hline 22 & 22.56 & 56.73 & 2.535 & 0.2 & 0.63 & 122 & 11:45 & 2.28 \\
\hline 23 & 22.56 & 56.73 & 2.535 & 0.25 & 0.85 & 115.6 & 12:00 & 2.26 \\
\hline 24 & 22.56 & 56.73 & 2.535 & 0.35 & 1.37 & 101.6 & $12: 15$ & 2.21 \\
\hline 25 & 22.56 & 65.24 & 2.535 & 0.3 & 1.09 & 131.9 & $12: 00$ & 2.31 \\
\hline 26 & 22.56 & 48.22 & 2.535 & 0.3 & 1.09 & 86.1 & $12: 00$ & 2.15 \\
\hline 27 & 22.56 & 56.73 & 3.28 & 0.2 & 0.82 & 106 & $12: 15$ & 2.23 \\
\hline 28 & 22.56 & 56.73 & 3.28 & 0.25 & 1.09 & 99.9 & $12: 30$ & 2.21 \\
\hline 29 & 22.56 & 56.73 & 3.28 & 0.3 & 1.41 & 93.4 & $12: 30$ & 2.19 \\
\hline 30 & 22.56 & 56.73 & 3.28 & 0.35 & 1.77 & 86.9 & $12: 45$ & 2.16 \\
\hline 31 & 22.56 & 56.73 & 1.79 & 0.2 & 0.45 & 145.2 & $11: 30$ & 2.35 \\
\hline 32 & 22.56 & 56.73 & 1.79 & 0.25 & 0.60 & 139.2 & $11: 30$ & 2.33 \\
\hline 33 & 22.56 & 56.73 & 1.79 & 0.3 & 0.77 & 131.8 & $11: 30$ & 2.31 \\
\hline
\end{tabular}

Not having observed runoff data at the catchment's outlet, we could not use statistical indices such as Nash-Sutcliffe to calibrate the model. Instead, we collected the most considerable runs (42) in order to better approach the aforementioned calibration and validation criterion. We believe that with the method followed, we approached quite sufficiently the range of uncertainty of the resulted hydrograph. Using methods such as Monte Carlo sampling would be appropriate if we had adequate field data, which is not the case in our study.

One parameter was changed each time, with the bold characters in Table 2 showing the parameters that are calibrated in each test. The uncertainty of $\pm 15 \%$ in $C N$ produces peak discharges of the modeled hydrograph equal to $86.1 \mathrm{~m}^{3} / \mathrm{s}$ and $131.9 \mathrm{~m}^{3} / \mathrm{s}$, respectively. It should be noticed that uncertainty tests of $C N$ calculation by $\pm 5 \%$ were also examined, showing peak discharges between $101.3 \mathrm{~m}^{3} / \mathrm{s}$ and $116.7 \mathrm{~m}^{3} / \mathrm{s}$. The 42 calibration trials of the hydrological model with variable parameters produced equal number of hydrographs, with the time of appearance of peak discharge occurring between 11:30 and 12:45 of 17 October. The hydrographs were used as an input to the hydraulic model, with the latter producing a maximum flood depth in the post-flood control cross section between $2.15 \mathrm{~m}$ to $2.35 \mathrm{~m}$. The best combination of the four examined parameters that provide the best match of measured and simulated flood wave depth at the reported peak time of the flood wave passing are the impervious rate equal to $22.56 \%$, the $C N$ equal to 56.73 , the time of concentration $T_{\mathcal{c}}$ equal to $2.535 \mathrm{~h}$ and the 
storage coefficient $R$ equal to $1.09 \mathrm{~h}$, in which case the peak discharge was estimated $109 \mathrm{~m}^{3} / \mathrm{s}$ at 12:00 of 17 October 2006, leading to a modeled average depth in the downstream cross section of $2.24 \mathrm{~m}$. In Figure 5, apart from rainfall's distribution of the severe event, the modeled shaded flow hydrographs depicted the uncertainty of the results based on the relevant parameters.

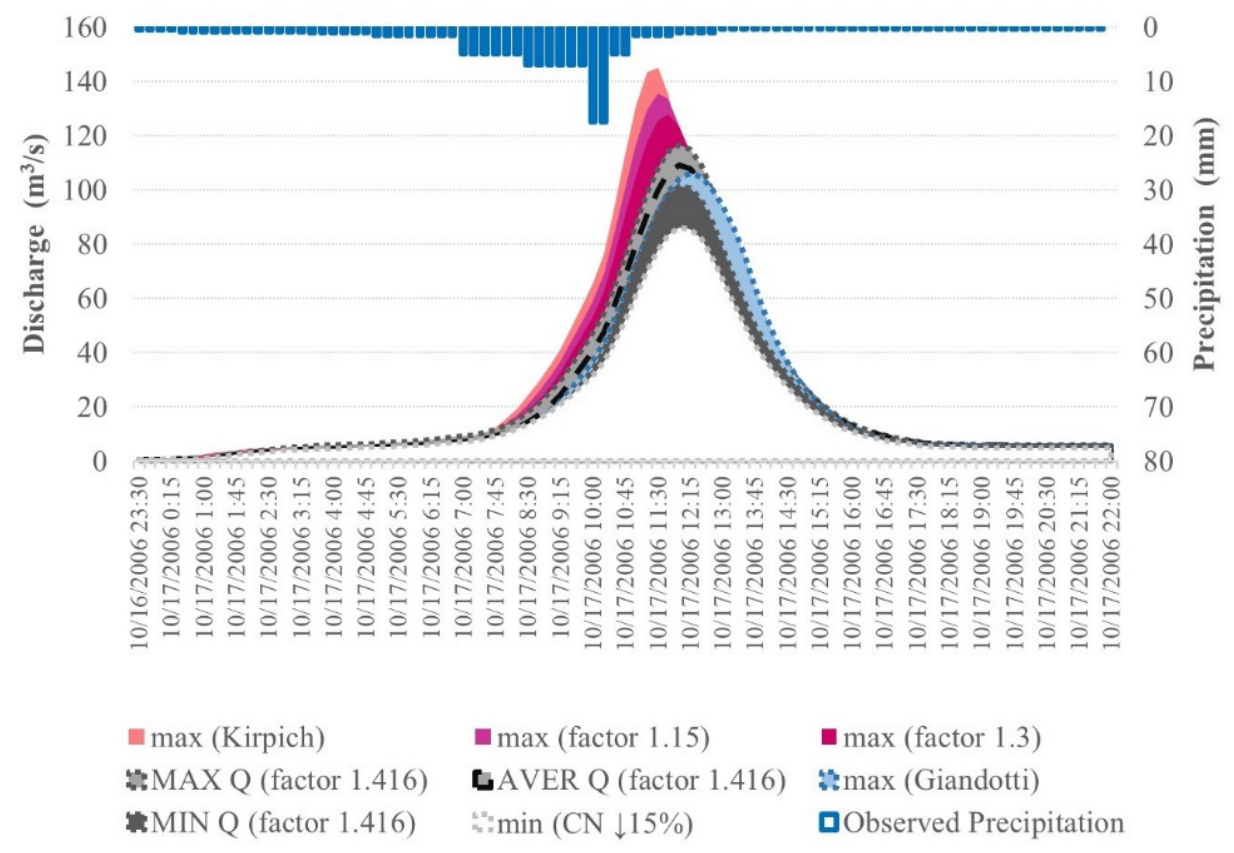

Figure 5. Observed precipitation and modeled discharge with uncertainty limits, of 2006 Almyrida flash flood.

\subsection{Hydrological Modeling Output}

Assessing the results of the hydrological HEC-HMS 4.2.1 model, providing the best fit between measured and modeled depth in downstream cross section, the peak discharge of $109 \mathrm{~m}^{3} / \mathrm{s}$ took place on 17 October 2006 at 12:00, that was $1 \mathrm{~h}$ and $30 \mathrm{~min}$ to $1 \mathrm{~h}$ and $45 \mathrm{~min}$ after the occurrence of the maximum rainfall of $17.50 \mathrm{~mm}$, taking place at 10:15 and 10:30 of the same day. The total precipitation depth, from 16 October at 23:30 to 18 October at 22:00, was $196.20 \mathrm{~mm}$, of which $97.27 \mathrm{~mm}$ were infiltrated (loss), while $98.93 \mathrm{~mm}$ was the excess depth. Of the excess depth, $96.80 \mathrm{~mm}$ runoff directly, while $1.62 \mathrm{~mm}$ was the baseflow depth. Therefore, the total discharge depth of precipitated water was $98.42 \mathrm{~mm}$. On 17 October at 10:30, the maximum water depth that did not penetrate into the ground was measured, with a value of $11.14 \mathrm{~mm}$. On the same day, at 10:15, the maximum water loss was observed, equal to $7.23 \mathrm{~mm}$.

\subsection{Hydraulic Modeling Output}

Evaluating the results of the 1D hydraulic simulation of the downstream reach via the 1D HEC-RAS 5.0.3 model, by using high resolution DTM $5 \mathrm{~m} \times 5 \mathrm{~m}$, the velocity in the channel varied between $0.32 \mathrm{~m} / \mathrm{s}$ and $4.10 \mathrm{~m} / \mathrm{s}$, due to the elevations variation of the channel bed and the variable channel width as well. For high slopes, high velocities were simulated, while for increased channel widths, reduced velocities were noticed. Additionally, water velocities were reduced near the bridge. In the control cross section, the hydraulic simulation average water depth reached $2.24 \mathrm{~m}$, in agreement with the post-flood field measurement, taking into account the uncertainty, having a range from $2.15 \mathrm{~m}$ to $2.32 \mathrm{~m}$. From upstream until before the bridge, the total energy of the system was clearly higher than the floodwater surface, whereas the water surface and energy line are much alike just before and shortly after the bridge. Therefore, the upstream increased velocity is more likely to affect the total energy of the system than the one near the bridge. At the downstream, the flooded area was 
increased, with the largest flooded surface appearing from 11:50 to 12:50, confirming the peak results from HEC-HMS. In Figure 6a, the flood extent at peak discharge and the maximum flood depths are shown, whereas the maximum flood wave velocities during the 1D hydraulic simulation are displayed in Figure 6b, using the RAS Mapper. Flood depth has reached up to $4.56 \mathrm{~m}$ approximately $7 \mathrm{~m}$ before the bridge, while the bridge also flooded by about $0.27 \mathrm{~m}$. On the other hand, maximum flood wave velocities were recorded in about half of the total downstream segment of the stream and reached a maximum speed of $5.05 \mathrm{~m} / \mathrm{s}$ locally.

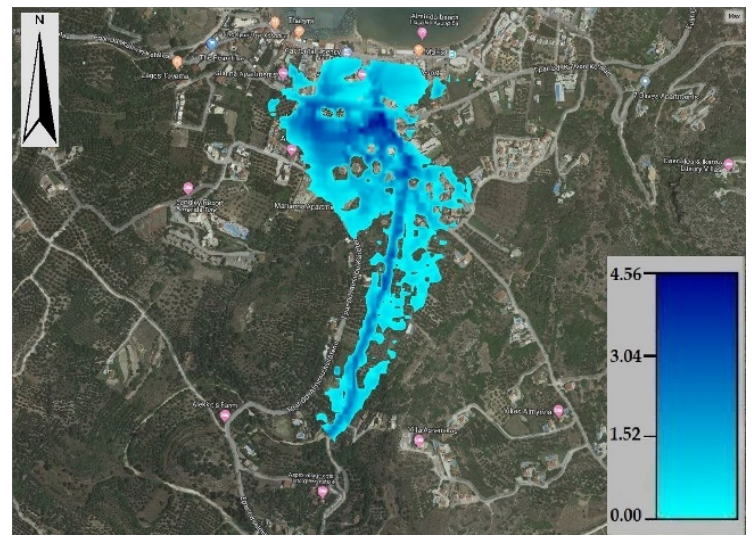

(a)

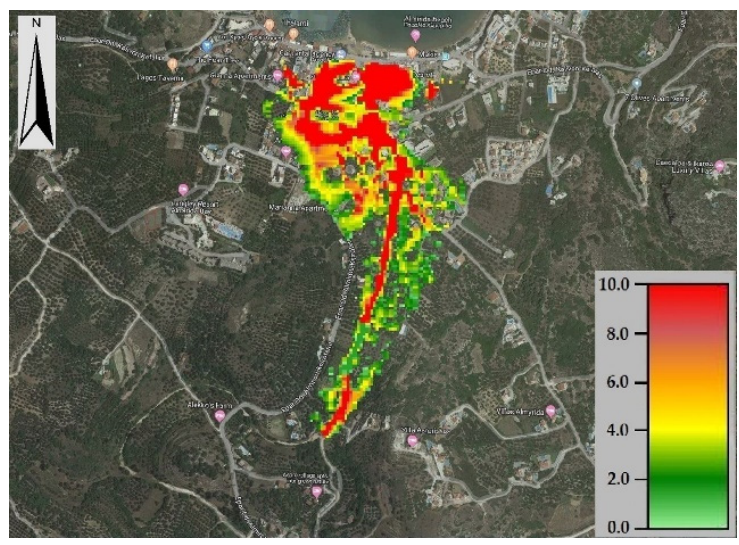

(c)

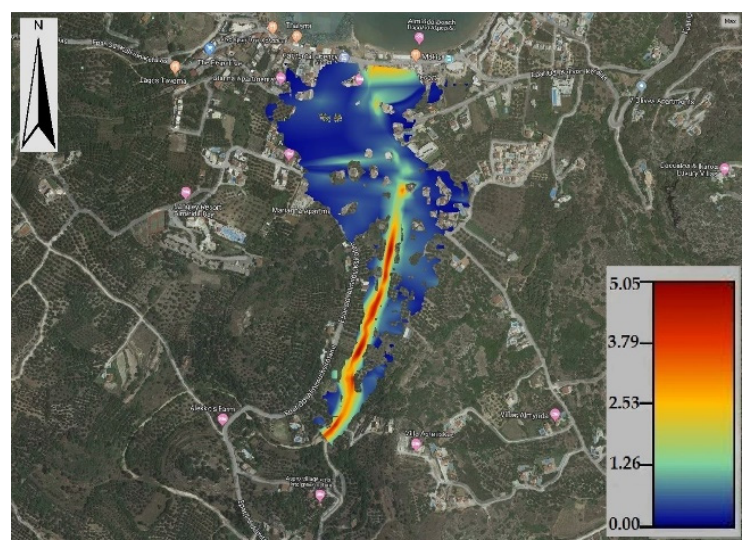

(b)

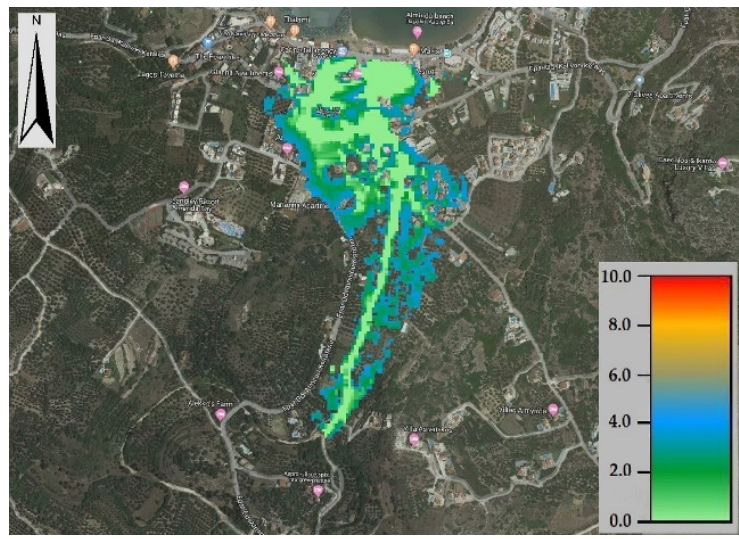

(d)

Figure 6. (a) Flood extent and maximum flood depths; (b) maximum flood wave velocities in plan view, at peak flow; (c) flood duration since the start of simulation; (d) flood wave arrival time at flow areas, through the hydraulic 1D HEC-RAS 5.0.3 model, by using high resolution DTM $5 \mathrm{~m} \times 5 \mathrm{~m}$.

In Figure 6c, the flooded areas' duration since the beginning of the hydraulic 1D simulation is represented. Some of the flow areas remained flooded within $10 \mathrm{~h}$ of hydraulic simulation. Only a few areas were flooded for $8 \mathrm{~h}$ to $4 \mathrm{~h}$; nevertheless, there were some areas being flooded for only $2 \mathrm{~h}$. In Figure $6 \mathrm{~d}$, the arrival time of the flood wave at flow areas is displayed. In areas previously identified as being flooded throughout the simulation, the arrival time was instant. However, the flood wave arrived later in other areas of the flood extent; some of them flooded up to $4.13 \mathrm{~h}$ later from the beginning of the hydraulic simulation. Even so, mapping of Figure $6 \mathrm{c}$,d cannot be totally accurate, because there is no detailed design of the modeled area through grid cells, but only through cross sections.

\subsection{Climate Change Scenarios for the Event Precipitation Depth}

For the observed $196.2 \mathrm{~mm}$ total precipitation depth, from 16 October 2006 at 23:30 to 18 October 2006 at 22:00, various scenarios of climate change were examined. From the precipitation data observed 
at quarterly hour, a peak rainfall of $17.50 \mathrm{~mm}$ occurred at 10:15 and 10:30 on 17 October, resulting in an average peak discharge of $109 \mathrm{~m}^{3} / \mathrm{s}$. The same cumulative precipitation was examined by distributing it differently over time. Specifically, the peak rainfall was decreased by 0.57 and 0.34 times, and additionally, was increased by a factor of 2.0 and 4.0, reaching the values of $7.5 \mathrm{~mm}$ and $11.5 \mathrm{~mm}$ for the peak rainfall decrease scenarios, and the values of $35 \mathrm{~mm}$ and $70 \mathrm{~mm}$ in case of the rain increase scenarios, at 10:15 and 10:30 of 17 October 2006, respectively. The resulted peak discharges reached $85.4 \mathrm{~m}^{3} / \mathrm{s}, 106.2 \mathrm{~m}^{3} / \mathrm{s}, 130.6 \mathrm{~m}^{3} / \mathrm{s}$ and $192.2 \mathrm{~m}^{3} / \mathrm{s}$ correspondingly; the latter being $76 \%$ increased as compared to the baseline scenario. The resulting flow hydrographs are shown in Figure 7 . The time of peak discharge appears at 12:00 in case of decrease of peak rainfall, and at 12:15 for the increased peak precipitation scenarios.

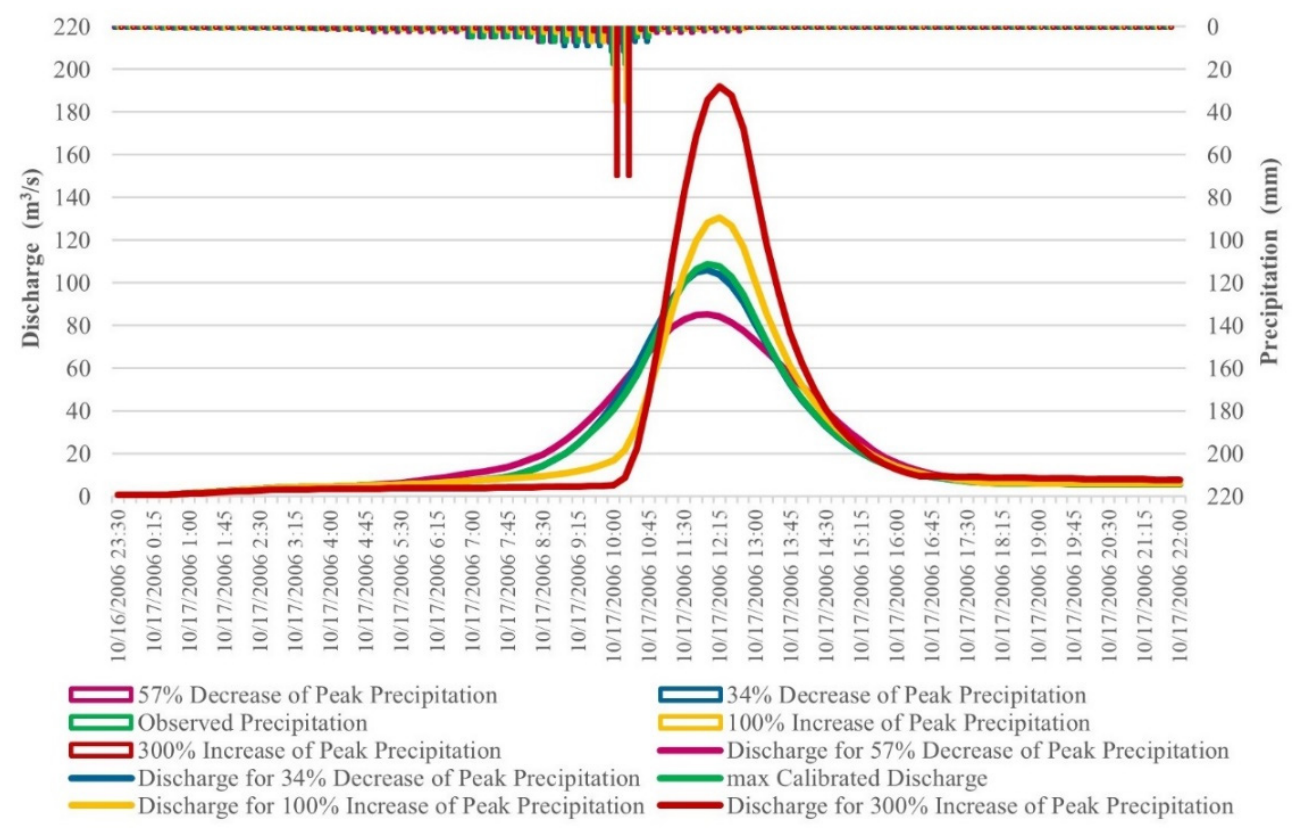

Figure 7. Precipitation and modeled flow hydrograph due to climate change scenarios of decrease of peak rainfall by $57 \%$ and $34 \%$, as well as a peak rainfall increase by $100 \%$ and $300 \%$.

The intensity peaking factor was also examined, either in maximum $15 \mathrm{~min}$, or in hourly mode, with the rainfall intensity to be considered between 10:15 and 11:15 of 17 October 2006. For the latter, the observed rainfall was equal to $45 \mathrm{~mm} / \mathrm{h}$. Concerning the examined climate change scenarios, the intensity of rainfall reached values of $25 \mathrm{~mm} / \mathrm{h}$ and $37 \mathrm{~mm} / \mathrm{h}$ regarding the peak rainfall decrease scenarios, and values of $75 \mathrm{~mm} / \mathrm{h}$ and $143 \mathrm{~mm} / \mathrm{h}$ due to the increase of the peak rainfall scenarios. The intensity peaking factor was defined as the ratio of the rainfall intensity of a climate change scenario to the baseline precipitation intensity, and the peak discharge runoff ratio was defined as the ratio of the discharge of a climate change scenario to the basic runoff. Figure 8 shows that there is a clear upward trend of the intensity peaking factor; yet, the peak outflows depend on the peak discharge runoff ratio, with the latter following a linear trend.

Different time distributions of total precipitation may lead to variations of simulated peak discharge. Scenarios of distributing the $15 \mathrm{~min}$ observed data to $5 \mathrm{~min}$ data, $30 \mathrm{~min}$ data or even $1 \mathrm{~h}, 3 \mathrm{~h}, 6 \mathrm{~h}, 12 \mathrm{~h}$ and $24 \mathrm{~h}$ data are simulated. Those scenarios are considered for the base peak precipitation of $17.50 \mathrm{~mm}$, as well as for an increase of peak precipitation by a factor of 2.0 and 4.0, corresponding to peak precipitation of $35 \mathrm{~mm}$ and $70 \mathrm{~mm}$, but for the same total amount of precipitation as of the base scenario. Modeling with a precipitation time step of more than $1 \mathrm{~h}$ revealed significant changes to modeled peak discharge, as shown in Figure 9. It is recommended that the precipitation intensity should be less than one hour, in order for the flow hydrographs and the peak discharges to be independent from the time step. 


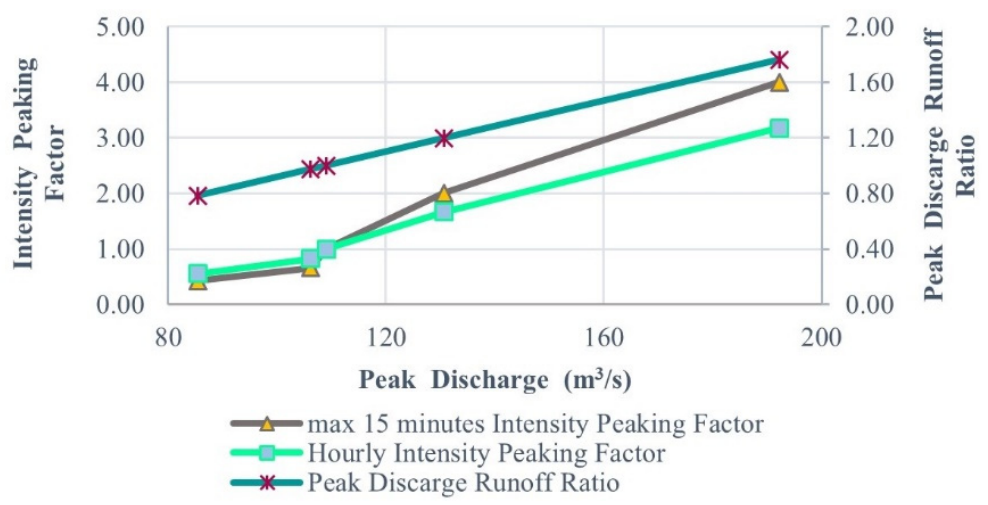

Figure 8. Intensity peaking factor and peak runoff ratio resulting from decrease of the peak rainfall by $57 \%$ and $34 \%$, as well as from increase of the peak rainfall by $100 \%$ and $300 \%$.

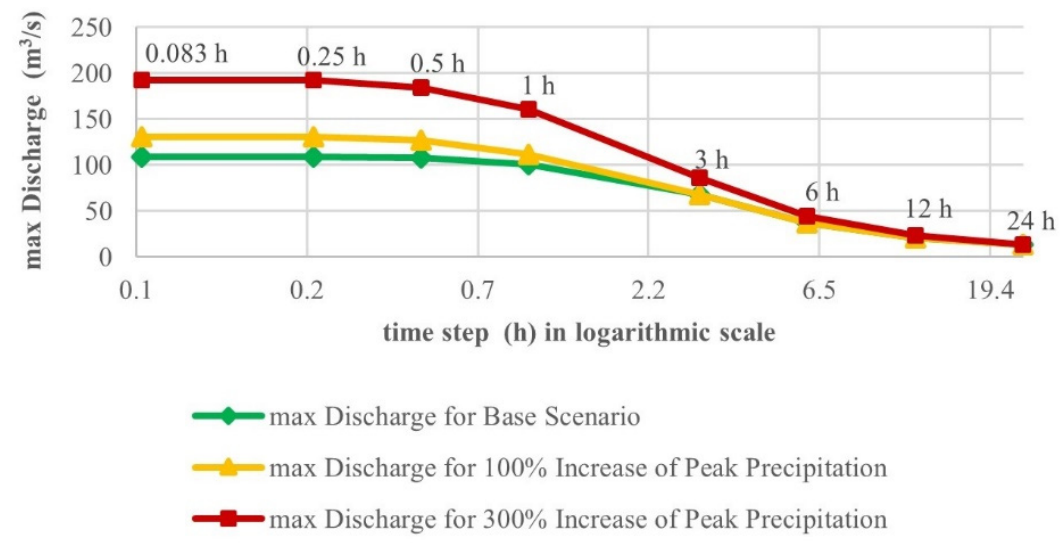

Figure 9. Scenarios of different rainfall's temporal distribution data and simulated peak discharges.

For the event precipitation depth of $196.2 \mathrm{~mm}$, regarding the aforementioned discharges which result from the examined climate change scenarios, the maximum flood depth and the flood extent are identified, as derived from the high resolution DTM $5 \mathrm{~m} \times 5 \mathrm{~m}$, through the 1D hydraulic simulation of the downstream reach, and the results are shown in Figure 10. Both the resulting maximum flood depth and flood extent have an upward trend as the peak discharge increases. When the peak discharge is expected to be equal to $85.4 \mathrm{~m}^{3} / \mathrm{s}$, in case the peak rainfall is decreased by $57 \%$, the maximum flood depth becomes equal to $4.48 \mathrm{~m}$, whereas the flood extent area reaches $84,916 \mathrm{~m}^{2}$. On the other hand, increase of the peak precipitation by a factor of 4.0 results to a maximum runoff equal to $192.2 \mathrm{~m}^{3} / \mathrm{s}$, which is 2.25 times the above mentioned, a maximum flood depth of $4.77 \mathrm{~m}$, while the flood extent reaches $113,977 \mathrm{~m}^{2}$, about $34 \%$ increase by the resulting one for runoff of $59.9 \mathrm{~m}^{3} / \mathrm{s}$.

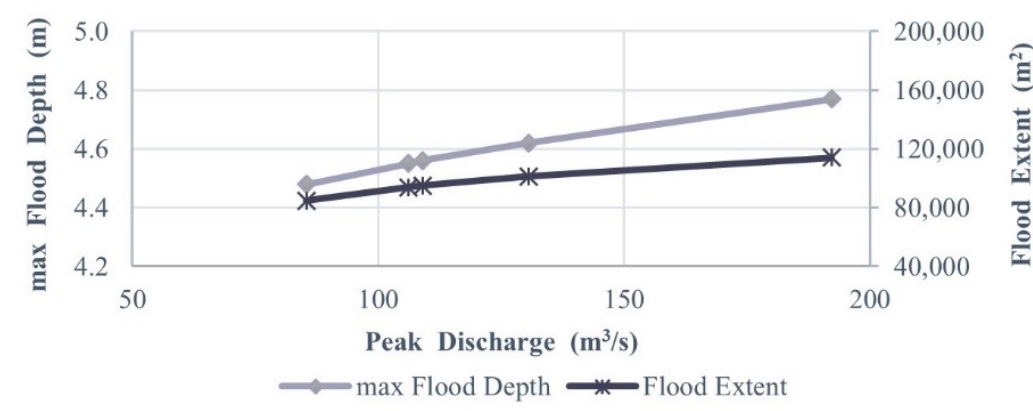

Figure 10. Maximum flood depth $(\mathrm{m})$ and flood extent $\left(\mathrm{m}^{2}\right)$ resulting from the observed precipitation, as well as decrease of the peak rainfall by $57 \%$ and $34 \%$, and increase of the peak rainfall by $100 \%$ and $300 \%$. 
For the examined climate change scenarios, the average flood duration and the maximum flood wave arrival time at all flow areas are simulated as well. For the baseline scenario, the average flood duration was equal to $5.45 \mathrm{~h}$, where in case of peak precipitation's increase by a factor of 4.0, flood duration was, on average, decreased by $14.5 \%$. The maximum flood wave arrival time at all flow areas was identified to be equal to $4.13 \mathrm{~h}$ regarding the basic scenario, while it was increased by $6 \%$ in case of increase of peak precipitation by a factor of 4.0 .

\section{Discussion}

Average precipitation is likely to be reduced in the Eastern Mediterranean due to climate change that will cause intensification of the hydrological cycle, and will produce higher rainfall intensities in shorter periods of time [49]. Due to severe storms passing over Crete, various gauges near the Almyrida basin have already measured more intense sub-hourly precipitation. This may result in heavy rainfall passing over the studied basin. Due to the small size of the basin and the absence of high-resolution temporal data, a precipitation data station gave the total daily precipitation of the studied event. In addition, data were collected at a frequency of every three hours from another nearby station. Climate projections that appear in the EURO-CORDEX database are of $12.5 \mathrm{~km} \times 12.5 \mathrm{~km}$ spatial resolution, which are not used in Almyrida basin due to its small size (an order of magnitude smaller than the grid size of the CORDEX). Moreover, the climate data are provided daily, which is not appropriate for flash flood analysis. In semi-arid areas of Crete, as with the studied basin, the precipitation intensity is required at a sub-hourly scale. Therefore, it is difficult to obtain good results from projecting the data, as the minimum requirement is 30 years of 10-min interval data, but the only available data were recorded for the last 5 years. We consider that the examined scenarios of changing the peak precipitation and redistributing the remaining event rainfall depth are very likely to happen due to the fact that other hydrometric stations of Chania's Prefecture have already recorded higher precipitation, with daily rain events of the order of $400 \mathrm{~mm}$. The objectives of the paper are based in the response of a small basin being studied under a flash flood event, without having adequate field data. Even the gauged runoff in watersheds cannot be measured in heavy precipitation events, because of the destruction of the discharge measuring equipment. Koutroulis et al. [10] calibrated the peak discharge of a flash flood event at a different basin of Crete, through the analysis of previously calculated hydrographs of rainfall events, which did not cause floods and damages to existing runoff gauges. In our case study, we used a hydrological model (HEC-HMS) and validated the simulated hydrographs by using the hydraulic model (HEC-RAS) with post-flood data. In order to improve flood risk management in the study area, the development of improved flood mapping is required and has to include the climate change impact. Therefore, a number of possible changing climate scenarios are applied to explore this effect in the magnitude of peak hydrograph and the flood extent.

In order to better approach the impacts of severe flood events in the future, decision makers should take into account the size of the particular area and the time step used in the simulation when analyzing the flood event. Tapoglou et al. [27] already mentioned the need for a lower than daily time step of analysis, in order to investigate the possible risks of hydro-meteorological extremes in Crete's basins. Vozinaki et al. [13] have also stated the urgency for sub-daily data for more precise climate change projections on Mediterranean catchments. With respect to the time step of precipitation records, the hydrological analysis shows that for small basins of a similar size, time step data of $1 \mathrm{~h}$ or more does not produce reliable results on modeling peak discharge for short-duration and high-intensity precipitation events. As shown in Figure 9, with respect to the base scenario, daily data provided a peak discharge equal to $13.3 \mathrm{~m}^{3} / \mathrm{s}, 12 \mathrm{~h}$ precipitation data provided a maximum discharge of $20.9 \mathrm{~m}^{3} / \mathrm{s}$, whereas $6 \mathrm{~h}$ precipitation time-series data produced peak runoff equal to $37.4 \mathrm{~m}^{3} / \mathrm{s}$. In order to achieve the validated hydrograph, we need to collect sub-hourly precipitation data. 


\section{Conclusions}

Floods Directive 2007/60/EC [50], which entered into effect in November 2007, requested the EU Member States to prepare flood hazard and flood risk maps at the level of the river basin. The exact determination of a flood extent based on highly accurate topographic data is of primary importance for the development of such detailed maps. The studied watershed is particularly prone to floods and the procedure followed will assist flood risk management planning, so that the potential impacts of future flash floods to civil, environmental and economic activities are minimized.

For the different kind of storm types that crossed over Crete during previous years, rainfall intensities were recorded at neighboring stations outside of the Almyrida watershed at a sub-hourly time step. This was higher than the studied time step of $45 \mathrm{~mm} / \mathrm{h}$, showing the expected intensification of the hydrological cycle due to climate change. We believe that the sub-hourly rainfall intensities will further increase. From the data that we have from neighboring stations about other extreme events caused by climate change, we have identified peaks of precipitation equal to $20-25 \mathrm{~mm}$ in $10 \mathrm{~min}$, which are higher from the one used in our case study. That was the reason for examining the cases of climate change impact to the peak of the event precipitation increased by a factor of 2.0 and 4.0 and redistributing differently the rest of the cumulative precipitation. Due to limited sub-hourly precipitation data, available only for the last 5-year period, two other extreme rainfall events were used to identify the rainfall's distribution in a sub-hourly time step. For the studied heavy rainfall event, 15-min interval data were used as the best sub-hourly rainfall distribution to produce a flow hydrograph. The hydrological model was run with an increased peak precipitation by a factor of 2.0 , and this resulted in a peak discharge of $130.6 \mathrm{~m}^{3} / \mathrm{s}$ as presented in Figure 6 . This will probably occur according to precipitation records taken at nearby stations. The resulting daily rainfall from the EURO-CORDEX database (projection to 2100) with a spatial resolution of $12.5 \mathrm{~km} \times 12.5 \mathrm{~km}$ that was projected to reach up to $350 \mathrm{~mm}$. Analysis of storm events of the last 5-year period found that the ratio of daily to hourly precipitation is $6.16 \pm 3.49$, which corresponds to an hourly precipitation between $36.3 \mathrm{~mm} / \mathrm{h}$ to $131.1 \mathrm{~mm} / \mathrm{h}$, being in a similar range between the base scenario and the expected scenario of increased peak precipitation by a factor of 4.0 due to climate change.

The modeled peak discharge of the severe precipitation event of 17 October 2006 in the Almyrida basin produces water depth at the control section that is in agreement with the post-flood field measurements. Uncertainty factors in calculating hydrological parameters play a determinant role in the approach of the actual hydrograph and the determination of flood impact. The impervious rate, the curve number $C N$, the time of concentration $T_{c}$ and the storage coefficient are the most important parameters that affect the produced peak discharge, with the $T_{c}$ being the most sensitive parameter, producing large time shifts and variations of peak runoff. The simulated average peak discharge of 109 $\mathrm{m}^{3} / \mathrm{s}$ is validated accounting for an average value of the impervious rate and an adjusted Kirpich's equation. The variation of land uses presents an uncertainty in the calculation of $C N$ that produces a varying peak hydrograph from $86.1 \mathrm{~m}^{3} / \mathrm{s}$ to $131.9 \mathrm{~m}^{3} / \mathrm{s}$. Without an adjustment factor to estimate $T_{\mathcal{C}}$, Kirpich's formula produces a peak discharge of $145.2 \mathrm{~m}^{3} / \mathrm{s}$. Application of Giandotti's equation in calculating the $T_{c}$ leads to a maximum peak discharge of $106 \mathrm{~m}^{3} / \mathrm{s}$. With respect to the uncertainty limits of the storage coefficient, a reduction produces an increase in peak discharge, whereas an increase leads to a decrease of the modeled peak. The examined climate change scenarios, considering the event precipitation volume, showed not only that the peak discharge changes significantly, but there is also a shift in the time of peak discharge. The relation of peak outflow to peak discharge runoff ratio, as well as the maximum of 15-min rainfall peaking factor and the hourly intensity peaking factor follows an upward trend. Modeling with different time steps of precipitation, the peak discharge varies significantly. For a catchment of a similar area, less than half an hour time step of rainfall data is recommended to be used, in order to achieve reliable flow hydrographs. Climate change has a notable relation to the flood extent. The use of the topography of a DTM $5 \mathrm{~m} \times 5 \mathrm{~m}$ revealed an increase of $20 \%$ in the area extent for the scenario of increased peak precipitation by a factor of 4.0 , whereas there was only a $4.6 \%$ increase in the maximum flood depth compared to the basic 
scenario. The corresponding velocity in the control cross-section is also increased by $57 \%$ compared to the baseline scenario. However, it is crucial to use higher resolution DTM in order to increase the accuracy of the flood extent. Regarding the simulated base scenario, the maximum flooded area took place between 11:50 and 12:50, which is in agreement to the arrival time of peak discharge to the control cross-section.

Author Contributions: Conceptualization, S.S. and I.T.; methodology, S.S.; software, S.S.; validation, S.S.; formal analysis, S.S.; investigation, S.S.; data curation, S.S.; writing —original draft preparation, S.S.; writing-review and editing, S.S. and I.T.; visualization, S.S.; supervision, I.T.; funding acquisition, I.T.

Funding: This research was partly funded by the Horizon 2020 Framework programme through the project IMPREX, grant agreement No. 641811. The APC was funded by Technical University of Crete.

Acknowledgments: The research reported of this paper was supported by the project IMPREX.

Conflicts of Interest: The authors declare no conflict of interest.

\section{References}

1. Hapuarachchi, H.A.P.; Wang, Q.J; Pagano, T.C. A review of advances in flash flood forecasting. Hydrol. Process. 2011, 25, 2771-2784. [CrossRef]

2. Gourley, J.J.; Flamig, Z.L.; Vergara, H.; Kirstetter, P.-E.; Clark III, R.A.; Argyle, E.; Arthur, A.; Martinaitis, S.; Terti, G.; Erlingis, J.M.; et al. The FLASH Project: Improving the Tools for Flash Flood Monitoring and Prediction across the United States. Bull. Am. Meteorol. Soc. 2017, 98, 361-372. [CrossRef]

3. Terti, G.; Ruin, I.; Anquetin, S.; Gourley, J.J. A Situation-Based Analysis of Flash Flood Fatalities in the United States. Bull. Am. Meteorol. Soc. 2017, 98, 333-345. [CrossRef]

4. Rozalis, S.; Morin, E.; Yair, Y.; Price, C. Flash flood prediction using an uncalibrated hydrological model and radar rainfall data in a Mediterranean watershed under changing hydrological conditions. J. Hydrol. 2010, 394, 245-255. [CrossRef]

5. Borga, M.; Anagnostou, E.N.; Bloschl, G.; Creutin, J.-D. Flash flood forecasting, warning and risk management: The HYDRATE project. Environ. Sci. Policy 2011, 14, 834-844. [CrossRef]

6. Koutroulis, A.G.; Tsanis, I.K.; Daliakopoulos, I.N. Seasonality of floods and their hydrometeorologic characteristics in the island of Crete. J. Hydrol. 2010, 394, 90-100. [CrossRef]

7. Vrochidou, A.-E.K.; Tsanis, I.K. Assessing precipitation distribution impacts on droughts on the island of Crete. Nat. Hazards Earth Syst. Sci. 2012, 12, 1159-1171. [CrossRef]

8. Iordanidou, V.; Koutroulis, A.G.; Tsanis, I.K. Mediterranean cyclone characteristics related to precipitation occurrence in Crete, Greece. Nat. Hazards Earth Syst. Sci. 2015, 15, 1807-1819. [CrossRef]

9. Koutroulis, A.G.; Vrohidou, A.-E.K.; Tsanis, I.K. Spatiotemporal Characteristics of Meteorological Drought for the Island of Crete. J. Hydrometeorol. 2011, 12, 206-226. [CrossRef]

10. Koutroulis, A.G.; Tsanis, I.K. A method for estimating flash flood peak discharge in a poorly gauged basin: Case study for the 13-14 January 1994 flood, Giofyros basin, Crete, Greece. J. Hydrol. 2010, 385, 150-164. [CrossRef]

11. Tsanis, I.K.; Seiradakis, K.D.; Daliakopoulos, I.N.; Grillakis, M.G.; Koutroulis, A.G. Assessment of GeoEye-1 stereo-pair-generated DEM in flood mapping of an ungauged basin. J. Hydroinform. 2014, 16, 1-18. [CrossRef]

12. IPCC. Climate Change 2014: Synthesis Report. Contribution of Working Groups I, II and III to the Fifth Assessment Report of the Intergovernmental Panel on Climate Change; IPCC: Geneva, Switzerland, 2014.

13. Vozinaki, A.-E.K.; Tapoglou, E.; Tsanis, I.K. Hydrometeorological impact of climate change in two Mediterranean basins. Int. J. River Basin Manag. 2018, 16, 245-257. [CrossRef]

14. Fonseca, A.R.; Santos, J.A. Predicting hydrologic flows under climate change: The Tâmega Basin as an analog for the Mediterranean region. Sci. Total Environ. 2019, 668, 1013-1024. [CrossRef]

15. Perra, E.; Piras, M.; Deidda, R.; Paniconi, C.; Mascaro, G.; Vivoni, E.R.; Cau, P.; Marras, P.A.; Ludwig, R.; Meyer, S. Multimodel assessment of climate change-induced hydrologic impacts for a Mediterranean catchment. Hydrol. Earth Syst. Sci. 2018, 22, 4125-4143. [CrossRef]

16. Koutroulis, A.G.; Grillakis, M.G.; Tsanis, I.K.; Jacob, D. Exploring the ability of current climate information to facilitate local climate services for the water sector. Earth Perspect. 2015, 2, 1-19. [CrossRef] 
17. Grillakis, M.G.; Koutroulis, A.G.; Komma, J.; Tsanis, I.K.; Wagner, W.; Blöschl, G. Initial soil moisture effects on flash flood generation-A comparison between basins of contrasting hydro-climatic conditions. J. Hydrol. 2016, 541, 206-217. [CrossRef]

18. Parisi, S.; Pascale, S.; Sdao, F.; Soupios, P. Assessment and mapping of the intrinsic vulnerability to pollution: An example from Keritis River Basin (Northwestern crete, Greece). Environ. Earth Sci. 2013, 70, 2659-2670. [CrossRef]

19. Verheye, W.; de la Rosa, D. Mediterranean soils. In Land Use, Land Cover and Soil Sciences; Verheye, W., Ed.; UNESCO-EOLSS Publishers: Oxford, UK, 2006.

20. Nemec, W.; Postma, G. Quaternary alluvial fans in southwestern Crete: Sedimentation processes and geomorphic evolution. In Alluvial Sedimentation; Marzo, M., Puigdefábregas, C., Eds.; Spec. Publs Int. Ass. Sediment Wiley-Blackwell: Oxford, UK, 1993; Volume 17, pp. 235-276. [CrossRef]

21. Shahrukh, M.; Soupios, P.; Papadopoulos, N.; Sarris, A. Geophysical investigations at the Istron archaeological site, eastern Crete, Greece using seismic refraction and electrical resistivity tomography. J. Geophys. Eng. 2012, 9, 749-760. [CrossRef]

22. European Environmental Agency. CORINE Land Cover 1990-2000 Changes (CLC2000). 2016. Available online: https://www.eea.europa.eu/data-and-maps/ (accessed on 19 December 2018).

23. Daliakopoulos, I.N.; Tsanis, I.K. A weather radar data processing module for storm analysis. J. Hydroinform. 2012, 14, 332-344. [CrossRef]

24. Jacob, D.; Petersen, J.; Eggert, B.; Alias, A.; Christensen, O.B.; Bouwer, L.M.; Braun, A.; Colette, A.; Déqué, M.; Georgievski, G.; et al. EURO-CORDEX: New high-resolution climate change projections for European impact research. Reg. Environ. Chang. 2014, 14, 563-578. [CrossRef]

25. Grillakis, M.G.; Koutroulis, A.G.; Tsanis, I.K. Multisegment statistical bias correction of daily GCM precipitation output. J. Geophys. Res. Atmos. 2013, 118, 3150-3162. [CrossRef]

26. Nerantzaki, S.D.; Efstathiou, D.; Giannakis, G.V.; Kritsotakis, M.; Grillakis, M.G.; Koutroulis, A.G.; Tsanis, I.K.; Nikolaidis, N.P. Climate change impact on the hydrological budget of a large Mediterranean island. Hydrol. Sci. J. 2019, 64, 1190-1203. [CrossRef]

27. Tapoglou, E.; Vozinaki, A.-E.K.; Tsanis, I.K. Climate Change Impact on the Frequency of Hydrometeorological Extremes in the Island of Crete. Water 2019, 11, 587. [CrossRef]

28. Scharffenberg, W. Hydrologic Modeling System HEC-HMS User's Manual; CPD-74A, Version 4.2; U.S. Army Corps of Engineers, Hydrologic Engineering Center: Davis, CA, USA, 2016.

29. Ford, D.T.; Hamilton, D. Computer Models for Water-Excess Management. In Water Resources Handbook; Mays, L.W., Ed.; McGraw-Hill: New York, NY, USA, 1996.

30. Feldman, A.D. Hydrologic Modeling System HEC-HMS Technical Reference Manual; CPD-74B; U.S. Army Corps of Engineers, Hydrologic Engineering Center: Davis, CA, USA, 2000.

31. United States Department of Agriculture. Urban Hydrology for Small Watersheds, TR-55, 2nd ed.; Natural Resources Conservation Service: Springfield, VA, USA, 1986.

32. Chow, V.T.; Maidment, D.R.; Mays, L.W. Applied hydrology; McGraw-Hill: New York, NY, USA, 1988; ISBN 0 07-010810-2.

33. Brunner, G.W. CEIWR-HEC. HEC-RAS, River Analysis System User's Manual; CPD-68, Version 5.0; U.S. Army Corps of Engineers, Hydrologic Engineering Center: Davis, CA, USA, 2016.

34. Brunner, G.W. HEC-RAS, River Analysis System Hydraulic Reference Manual; CPD-69, Version 5.0; U.S. Army Corps of Engineers, Hydrologic Engineering Center: Davis, CA, USA, 2016.

35. Tsanis, I.K.; Boyle, S. A 2D Hydrodynamic/Pollutant Transport GIS Model. Adv. Eng. Softw. 2001, 32, 353-361. [CrossRef]

36. Naoum, S.; Tsanis, I.K. A Multiple Linear Regression GIS Module using Spatial Variables to Model Orographic Rainfall. J. Hydroinform. 2004, 6, 39-56. [CrossRef]

37. United States Department of Agriculture. Engineering Hydrology Training Series, Module 104: Runoff Curve Number Computations; Soil Conservation Service: Washington, DC, USA, 1989.

38. United States Department of Agriculture. National Engineering Handbook, Chapter 7: Hydrologic Soil Groups; 210-VI-NEH; Natural Resources Conservation Service: Washington, DC, USA, 2009.

39. United States Department of Agriculture. National Engineering Handbook, Hydrology, Supplement A, Section 4; Soil Conservation Service: Washington, DC, USA, 1956; Chapter 10.

40. Giandotti, M. Previsione delle piene e delle magre dei corsi d'acqua. Ist. Poligr. Dello Stato 1934, 8, 107-117. 
41. Kirpich, P.Z. Time of concentration of small agricultural watershed. ASCE Civ. Eng. 1940, 10, 362-370. [CrossRef]

42. Sharifi, S.; Hosseini, S.M. Methodology for Identifying the Best Equations for Estimating the Time of Concentration of Watersheds in a Particular Region. J. Irrig. Drain. Eng. 2011, 137, 712-719. [CrossRef]

43. Efstratiadis, A.; Koussis, A.D.; Koutsoyiannis, D.; Mamassis, N. Flood design recipes vs. reality: Can predictions for ungauged basins be trusted? Nat. Hazards Earth Syst. Sci. 2014, 14, 1417-1428. [CrossRef]

44. Perdikaris, J.; Gharabaghi, B.; Rudra, R. Reference Time of Concentration Estimation for Ungauged Catchments. Earth Sci. Res. 2018, 7, 58-73. [CrossRef]

45. U.S. Army Corps of Engineers. Flood-Runoff Analysis Engineer Manual; EM 1110-2-1417; Engineering and Design: Washington, DC, USA, 1994.

46. Pilgrim, D.H.; Cordery, I. Flood runoff. In Handbook of Hydrology; Maidment, D.R., Ed.; McGraw-Hill: New York, NY, USA, 1993.

47. Cameron, T.; Ackerman, P.E. HEC-GeoRAS GIS Tools for Support of HEC-RAS using ArcGIS®10 User's Manual; CPD-83, Version 10; U.S. Army Corps of Engineers, Hydrologic Engineering Center: Davis, CA, USA, 2012.

48. Chow, V.T. Open-Channel Hydraulics; McGraw-Hill: New York, NY, USA, 1959.

49. Tsanis, I.K.; Koutroulis, A.G.; Daliakopoulos, I.N.; Jacob, D. Severe climate-induced water shortage and extremes in Crete. Clim. Chang. 2011, 106, 667-677. [CrossRef]

50. Directive on the Assessment and Management of Flood Risks; Official Journal of the European Union: Strasbourg, France, 2007; pp. L288/27-L288/34, EP \& CEU (2007/60/EC).

(C) 2019 by the authors. Licensee MDPI, Basel, Switzerland. This article is an open access article distributed under the terms and conditions of the Creative Commons Attribution (CC BY) license (http://creativecommons.org/licenses/by/4.0/). 